\title{
ПРОБЛЕМИ ЕКОЛОГІЧНОГО СТАНУ СЕРЕДНІХ РІЧОК У МЕЖАХ РІВНЕНСЬКОЇ ОБЛАСТІ
}

\author{
Мельник В. Й., Толочик І. Л.
}

\section{ВСТУП}

Небезпеку існування людини від локального до глобального рівня створюють екологічні проблеми, серед яких своєю актуальністю відзначаються i проблеми екологічного стану водних ресурсів. Ситуація із забрудненням річок у світі, й Україні зокрема, набуває критичного характеру ${ }^{1,2,3}$. Якість води у річках постійно погіршується через безсистемне і безконтрольне використання водних ресурсів, багатьом річкам загрожує повне зникнення, вони стають непридатними як джерело питної води, неможливо використовувати їхні басейни.

Внутрішні водойми Рівненщини представлені переважно річковими системами, густина мережі у середньому становить 270 м на 1 км $^{2}$ території ${ }^{4}$. Детальні дослідження річок у межах Рівненської області були проведені у 60-70-ті роки XX ст. під час паспортизації лише малих річок. Ліквідація басейнових управлінь у грудні 1988 р. повністю змінила підходи як до контролю якості води у річках, так і до наукових досліджень у цій галузі.

Використання річкових екосистем продовжує носити екстенсивний та руйнівний характер. Інтенсивне гідротехнічне будівництво на річках, створені водосховища, меліоративні канали тощо, нераціональне використання водних ресурсів вимагали спеціальних досліджень, які майже не проводилися. Окремі дослідження були спрямовані на вивчення впливу антропогенного навантаження, яке 3 року в рік посилюється, незважаючи на спад виробництва.

Слід зауважити, що в останні роки економічні негаразди в Україні відобразилися на роботі контролюючих обласних ланок Міністерства

1 Боярин М. Управління водними ресурсами басейну річки Іква в межах Рівненсьої області. Науковий вісник Східноєвропейського наџіонального університету ім. Л. Украӥнки. Луцьк, 2013. С. 38-42.

${ }^{2}$ Brannen L., Bielak A. (ed.) Threats to water availability in Canada. National Water Research Institute, Environment Canada, 2004.

${ }^{3}$ Gilvear D.J., Spray C.J., Casas-Mulet R. River rehabilitation for the delivery of multiple ecosystem services at the river network scale. J. Environ. Manage. 2013. № 126. P. 30-43. DOI:10.1016/j.jenvman.2013.03.026.

\footnotetext{
${ }^{4}$ Коротун I.М., Коротун Л.К. Географія Рівненської області. Рівне,1996. 273 с.
} 
екології та природних ресурсів і всіх суб'єктів контролю над якістю поверхневих вод. Екологічні інспекції проводять вибірковий контроль впливу скидів забруднених вод на якість води у тому чи іншому створі річки. Об'єктивні та суб'єктивні причини звели до мінімуму роботу суб'єктів моніторингу, контроль якості води у річках проводиться частково, переважно на транскордонних ділянках. Аналіз і оцінка гідрохімічної інформації основані суто на концепції гранично допустимих концентрацій, які мають виражений пороговий характер і не відображають об’єктивної картини процесів, які проходять у гідроекосистемі.

Сьогодення повністю змінило підходи до вирішення питання оцінки якості води, заставило по-іншому зрозуміти проблему та вдосконалювати шляхи їі вирішення. Для оцінки якості води річок необхідно враховувати як показники води як середовища існування, так і показники біотичного складника. Об'єктивну ж оцінку стану якості води річки неможливо зробити без комплексного підходу, оскільки на здатність процесів самоочищення впливає низка чинників, як зовнішнього впливу, так i внутрішніх закономірностей функціонування гідроекосистеми. Незважаючи на те що екосистеми річок належать до відновлювальних, відзначається їх постійне виснаження та забруднення.

Відомо, що без екологічної характеристики стану гідроекосистеми не можна оцінити іiї біологічну повноцінність. Вивченням оцінки якості поверхневих вод, удосконаленням їх класифікації займалися: В.Д. Романенко, О.Г. Васенко, Г.А. Верниченко, В.М. Жукінський, О.П. Оксіюк та ін., ${ }^{5,6}$.

Річки чутливі до антропогенного впливу, а їхній стан $\epsilon$ індикатором усієї річкової мережі кожної країни. В Україні антропогенне навантаження на басейни річок значно перевищує показники розвинутих країн світу.

Комплексну оцінку якості води річок представлено у статтях С.О. Афанасьєва, В.Й. Мельник, О.О. Бедункової ${ }^{7,8,9}$.

${ }^{5}$ Екологічна оцінка стану поверхневих вод України з урахуванням регіональних гідрохімічних особливостей / О.Г. Васенко та ін. Проблеми охорони навколишнього природного середовища та екологічної безпеки. 2010. Вип. XXXII. С. 36-54.

6 Методика екологічної оцінки якості поверхневих вод за відповідними категоріями / за заг. ред. В.Д. Романенко та ін. Київ : Символ-Т, 1998. 28 с.

7 Гідроекологічна характеристика басейну річки Іква та оцінка його стану / О.М. Лєтицька та ін. Наукові записки Тернопільського нац. педагогічного університету ім. В. Гнатюка. 2013. Вип. 3(56). С. 61-66.

${ }^{8}$ Мельник В.Й. Екологічні нормативи якості води річок у межах Рівненської області : монографія. Рівне : О. Зень, 2015. 290 с.

${ }^{9}$ Бєдункова О.О., Буднік 3.М. Оцінка екологічної шкоди та екологічного ризику гідрохімічних показників річки Іква. Вісник НУВГП. 2012. Вип. 4(60). С. 77-82. 
Важливе місце у дослідженнях займає вивчення проблем екологічного стану річок області. Незважаючи на значну кількість наукових публікацій, присвячених цьому питанню, ще не сформовано єдиної думки щодо таких понять, як «навантаження», «норма», «втрата якості води», «антропогенний складник» у гідроекосистемі тощо. Саме тому і виникла потреба вивчення проблем екологічного стану річок шляхом проведення оцінки антропогенного навантаження та визначення антропогенного складника і реальної екологічної втрати якості води р. Іква.

\section{1. Екологічна оцінка та втрата якості води р. Іква}

Об'єкт дослідження - басейн р. Іква. Розрахунок екологічної оцінки якості води річки проведений за «Методикою екологічної оцінки якості поверхневих вод за відповідними категоріями» ${ }^{10}$. Для грунтовного аналізу змін якості води у річці у сучасний період розрізнені дані лабораторії моніторингу вод і грунтів Рівненської гідромеліоративної експедиції, відділу інструментально-лабораторного контролю Державної екологічної інспекції у Рівненській області та власні дослідження, проведені в атестованій лабораторії, були систематизовані. Аналіз та оцінка якості води р. Іква досліджувалися у шести контрольних створах.

Розрахунок антропогенного навантаження проводили згідно «Методики розрахунку антропогенного навантаження і класифікації екологічного стану басейнів малих річок України» ${ }^{11} 3$ використанням показників Державної статистичної звітності 3 кількісного обліку земель форма «6-ЗЕМ» головного управління Держгеокадастру у Рівненській області та щорічних форм статистичної звітності 2ТП «Водгосп».

Мета роботи: визначити проблеми екологічного стану середніх річок у межах Рівненської області на прикладі р. Іква. Поставлена мета реалізується шляхом вирішення таких завдань:

- дослідити якість води річки Іква у сучасний період;

- визначити різницю між якістю води в сучасний період і встановленими екологічними нормативами;

- розрахувати реальну втрату якості води у річці;

10 Методика екологічної оцінки якості поверхневих вод за відповідними категоріями / за заг. ред. В.Д. Романенко та ін. Київ : Символ-Т, 1998. 28 с.

11 Методика розрахунку антропогенного навантаження i класифікації екологічного стану басейнів малих річок України / ред. А.В. Яцик та ін. Київ : УНДІВЕП, 2007. $71 \mathrm{c.}$ 
- комплексно вивчити та проаналізувати види антропогенного навантаження на басейн, розрахувати значення спільного впливу показників чотирьох підсистем i індукційний коефіцієнт антропогенного навантаження та визначити якісний стан системи «Басейн річки Іква»;

- розрахувати антропогенний складник змін якості води;

- провести комплексну оцінку екологічного стану басейну річки Іква.

Обробку та аналіз отриманих даних здійснювали методами математичної статистики 3 використанням сучасних комп'ютерних програм.

Річка Іква належить до басейну Стиря й $є$ іï правою притокою першого порядку. Басейн річки знаходиться на території Львівської, Тернопільської та Рівненської областей, витік - біля с. Черниця Львівської області. Загальна довжина - 156 км, 59,6\% русла знаходиться на території Рівненської області, що становить 62,2\% від загальної площі басейну, який включає дев'ять приток довжиною понад 10 км і 18 приток довжиною до 10 км. Коефіцієнт густоти річкової сітки без урахування приток, довжина яких менше 10 км, становить 0,14. Основними притоками Ікви у межах Рівненської області є річки Тартацька і Людомирка ${ }^{12}$. Берегова смуга річки налічує 26 населених пунктів.

Загальний напрям течії 3 південного заходу на північний схід відображає загальний похил поверхні басейну річки. Верхня течія р. Іква формується на північних схилах Волино-Подільської височини, а нижня - Поліською низовиною. Заплава переважно двостороння, подекуди заболочена, шириною від 100-200 до 650 м. Русло слабко звивисте, на окремих ділянках зарегульоване ставками та Млинівським водосховищем, ширина якого - 5-25 м, глибина - 0,5-2,2 м ${ }^{13}$. Іква належить до річок західно-поліського типу і має сезонний характер. Живлення річки - змішане $з$ перевагою підземного. Частка снігового живлення не перевищує 25-45\% і поступається підземному живленню до $55 \%{ }^{14}$. Вагоме місце у живленні річки займають дощові води. Унаслідок специфічних умов формування хімічного складу річкової води та значного впливу людської діяльності річка Іква характеризується відносно високою мінералізацією.

${ }^{12}$ Коротун І.М., Коротун Л.К. Географія Рівненської області. Рівне, 1996. 273 с.

${ }^{13}$ Коротун І.М., Коротун Л.К. Географія Рівненської області. Рівне, 1996. 273 с.

${ }^{14}$ Ганущак М.М. Роль водного чинника в розвитку і функціонуванні природноантропогенних комплексів басейну р. Стир : дис. ... канд. геогр. Наук : 11.00.11; Східноєвроп. нац. ун-т ім. Л. Українки. Луцьк, 2016. 242 с. 
У басейні зафіксовано велику кількість осушувальних каналів, дамб обвалування, призначених для захисту земель від затоплення під час весняної повені та паводків, споруджені меліоративні системи «Іква», «Тартацька» та ін. У результаті інтенсивних меліорацій у багатьох місцях заплава річки звужена дамбами польдерних осушувальних систем. На території Рівненської області річку Іква умовно поділяють на дві ділянки: перша ділянка - у межах Дубенського району, друга - у межах Млинівського району. Зі стічними водами у річку поступає велика кількість забруднюючих речовин, скид яких зазначений у формах 2 ТП «Водгосп» ${ }^{15}$, а динаміку відображено у табл. 1.

Таблиця 1

Скиди забруднюючих речовин у р. Іква

(за даними 2 ТП «Водгосп», 2015-2019 рр.)

\begin{tabular}{|c|c|c|c|c|c|}
\hline \multirow{2}{*}{$\begin{array}{c}\text { Забруднюючі } \\
\text { речовини }\end{array}$} & \multicolumn{4}{|c|}{ Обсяг забрудюючих речовин, т } \\
\cline { 2 - 6 } & $\mathbf{2 0 1 5}$ p. & $\mathbf{2 0 1 6} \mathbf{p .}$ & $\mathbf{2 0 1 7} \mathbf{p .}$ & $\mathbf{2 0 1 8}$ p. & $\mathbf{2 0 1 9}$ p. \\
\hline БСК $_{5}$ & 26,0 & 29,0 & 29,0 & 18,0 & 32,0 \\
\hline Завислі речовини & 24,0 & 25,0 & 26,0 & 18,0 & 21,0 \\
\hline Хлориди & 198,0 & 222,0 & 238,0 & 217,0 & 211,0 \\
\hline Сульфати & 83,6 & 84,0 & 94,0 & 87,0 & 91,0 \\
\hline Фосфати & 6,230 & 7,218 & 8,912 & 8,914 & 4,553 \\
\hline Азот амонійний & 6,0 & 7,0 & 8,0 & 4,0 & 6,0 \\
\hline Нітрити & 1,0 & 1,0 & 1,0 & 1,0 & 1,0 \\
\hline Нітрати & 1,0 & 1,0 & 2,0 & 1,0 & 1,0 \\
\hline Залізо & 0,396 & 0,344 & 0,307 & 0,215 & 0,256 \\
\hline
\end{tabular}

Основними забруднюючими речовинами води річки $є$ органічне забруднення та зважені речовини (рис. 1).

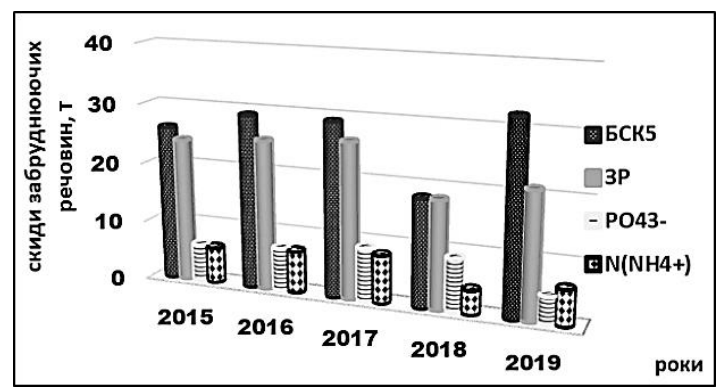

Рис. 1. Динаміка скиду основних забруднюючих речовин у р. Іква

${ }^{15}$ Статистична звітність, щорічна форма 2ТП «Водгосп» (2015-2019 pp.). 
Нині здійснюється вибірковий оперативний контроль якості води $\mathrm{p}$. Іква контролюючими організаціями, тому екологічна оцінка якості води у сучасний період проведена за даними результатів гідрохімічних аналізів проб води, виконаних в атестованій санітарній лабораторії BAT «Рівнеазот» у шести контрольних створах. Згруповані у порядку від витоку до гирла, тобто за течією річки, досліджувані контрольні створи у межах Рівненської області представлені в табл. 2.

Таблиця 2

\section{Створи досліджень якості води річки Іква у межах Рівненської області}

\begin{tabular}{|c|c|c|c|}
\hline $\begin{array}{c}\text { № } \\
\mathbf{3} \text { п }\end{array}$ & $\begin{array}{c}\text { Місцезнаходження } \\
\text { контрольного створу }\end{array}$ & $\begin{array}{c}\text { Відстань від } \\
\text { гирла, км }\end{array}$ & $\begin{array}{c}\text { Обгрунтування } \\
\text { необхідності } \\
\text { гідрохімічних } \\
\text { досліджень }\end{array}$ \\
\hline 1 & $\begin{array}{c}\text { с. Сапанівчик, у межах } \\
\text { села, на межі } \\
\text { Тернопільською областю }\end{array}$ & 80,5 & $\begin{array}{c}\text { Суміжний створ } \\
\text { Тернопільською } \\
\text { областю }\end{array}$ \\
\hline 2 & $\begin{array}{c}\text { с. Дитиничі, 4 км вище } \\
\text { міста Дубно, 0,2 км нижче } \\
\text { впадіння р. Тартацька }\end{array}$ & 50,0 & $\begin{array}{c}\text { Фоновий створ } \\
\text { для м. Дубно }\end{array}$ \\
\hline 3 & $\begin{array}{c}\text { м. Дубно, у межах міста, } \\
\text { 0,7 км вище скиду очисних } \\
\text { споруд Дубенської дільниці } \\
\text { «Рівнеоблводоканалу» }\end{array}$ & 43,4 & $\begin{array}{c}\text { Фоновий створ для } \\
\text { визначення впливу } \\
\text { стічних вод о/с } \\
\text { «Рівнеоблводоканалу» }\end{array}$ \\
\hline 4 & $\begin{array}{c}\text { м. Дубно, нижче скиду } \\
\text { стічних вод очисних споруд } \\
\text { Дубенської дільниці } \\
\text { «Рівнеоблводоканалу» }\end{array}$ & 42,9 & $\begin{array}{c}\text { Вплив скиду стічних } \\
\text { вод о/с }\end{array}$ \\
\hline 5 & $\begin{array}{c}\text { с. Іванне, у межах села, } \\
\text { нижче м. Дубно }\end{array}$ & 39,6 & $\begin{array}{c}\text { Вплив скидів стічних } \\
\text { вод м. Дубно }\end{array}$ \\
\hline 6 & $\begin{array}{c}\text { с. Торговиця, у межах села, } \\
1,5 \text { км вище гирла }\end{array}$ & 1,5 & $\begin{array}{c}\text { Контрольний створ } \\
\text { у гирлі }\end{array}$ \\
\hline
\end{tabular}

Через відсутність інформації у часі дані контрольних створів смт Млинів 0,5 км вище та 0,5 км нижче скидів стічних вод очисних споруд смт Млинів не були враховані під час досліджень.

Розрахунок екологічної оцінки якості води досліджуваної річки проведений згідно 3 «Методикою...»" ${ }^{16}$, яка на основі екологічних критеріїв дає змогу порівнювати якість води як на окремих ділянках річки, так і у водних об'єктах різних регіонів. Процедура визначення категорій якості води кожного показника за середніми та найгіршими

16 Методика екологічної оцінки якості поверхневих вод за відповідними категоріями / за заг. ред. В.Д. Романенко та ін. Київ : Символ-Т, 1998. 28 с. 
значеннями дає змогу абсолютні кількісні значення гідрохімічних показників переводити у кількісні, але ж відносні та уніфіковані інтегральні показники (категорії, субкатегорії, індекси, класи). Оцінка включає три блоки показників: блок сольового складу $\left(\mathrm{I}_{1}\right)$, трофосапробіологічний блок $\left(\mathrm{I}_{2}\right)$, блок показників специфічних речовин токсичної дії $\left(\mathrm{I}_{3}\right)$. Інтегральний екологічний індекс $\left(\mathrm{I}_{\mathrm{e}}\right)$ розрахований як середня величина трьох блокових індексів (рис. 2, 3).

Головною особливістю територіального розподілу показників сольового складу досліджуваної річки є чітка гідрохімічна зональність із північного заходу на південний схід, яка не залежить від напрямку течії i добре узгоджується 3 фізико-географічними зонами району дослідження. За показниками блоку сольового складу якість води віднесена до I класу та охарактеризована як «дуже чиста» 3 «відмінним» станом за середніми значеннями показників і «чиста» 3 «добрим» станом II класу за найгіршим значенням показників.

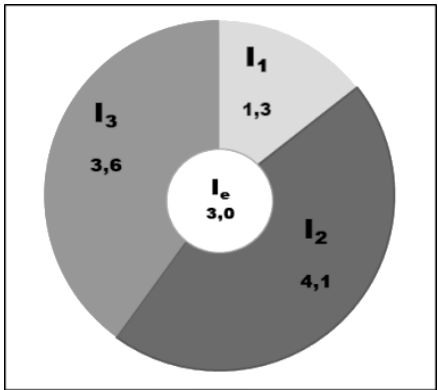

Рис. 2. Екологічна оцінка якості води р. Іква, середні значення, 2019 p.

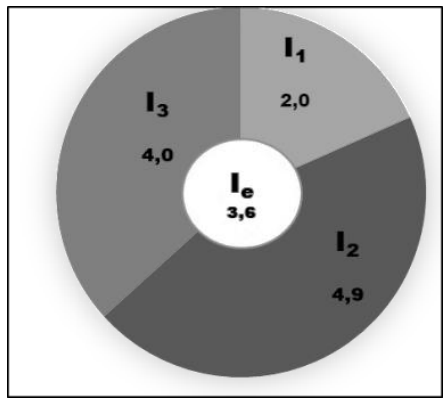

Рис. 3. Екологічна оцінка якості води р. Іква, найгірші значення, 2019 p.

Апріорі в оцінці якості води надано показникам трофосапробіологічного блоку. Блоковий індекс $\mathrm{I}_{2}$ визначений як 4,1 для середніх і 4,9 для найгірших значень показників. За ступенем чистоти вода охарактеризована , як «забруднена» із «задовільним» станом, III класу, евтрофна, $\beta$ "-мезосапробна за середніми i найгіршими значеннями показників.

За показниками блоку специфічних речовин токсичної дії вода $\mathrm{p}$. Іква $є$ перехідною від II до III класу якості й охарактеризована за ступенем чистоти як «чиста - забруднена» 3 «добрим - задовільним» станом за середніми значеннями та «забруднена» III класу якості із «задовільним» станом за найгіршими значеннями показників.

Визначено, що загалом по річці якість води погіршується за значеннями як усіх блокових, так і інтегрального екологічного індексів. За показниками середніх значень $\mathrm{I}_{\mathrm{e}}$ якість води віднесена до II класу, 
«чиста» 3 «добрим» станом, а за найгіршими значеннями вода $\epsilon$ перехідною від II до III класу якості з характеристикою «чиста забруднена» і «добрим - задовільним» станом.

Порівняння фактичних показників якості води у сучасний період із установленими оптимальними $\mathrm{i}$ допустимими екологічними нормативами для річок Рівненської області ${ }^{17}$ дало можливість 3 'ясувати зміни якості води р. Іква у категоріях (табл. 3).

Таблиця 3

Сучасні та нормативні значення показників якості води р. Іква у межах Рівненської області (2019 р.)

\begin{tabular}{|c|c|c|c|c|c|c|c|c|}
\hline \multirow{3}{*}{$\begin{array}{l}\text { Показники } \\
\text { якості води }\end{array}$} & \multicolumn{4}{|c|}{ Екологічні нормативи } & \multirow{2}{*}{\multicolumn{2}{|c|}{$\begin{array}{c}\text { Середні } \\
\text { значення }\end{array}$}} & \multirow{2}{*}{\multicolumn{2}{|c|}{$\begin{array}{l}\text { Найгірші } \\
\text { значення }\end{array}$}} \\
\hline & \multicolumn{2}{|c|}{$\mathbf{E H}_{0}$} & \multicolumn{2}{|c|}{$\mathbf{E H}_{\mathrm{I}}$} & & & & \\
\hline & $\begin{array}{l}\text { Зна- } \\
\text { чення }\end{array}$ & $\begin{array}{l}\text { Кате- } \\
\text { горії }\end{array}$ & $\begin{array}{l}\text { Зна- } \\
\text { чення }\end{array}$ & $\begin{array}{l}\text { Кате- } \\
\text { горії }\end{array}$ & $\begin{array}{l}\text { Зна- } \\
\text { чення }\end{array}$ & $\begin{array}{l}\text { Кате- } \\
\text { горії }\end{array}$ & $\begin{array}{l}\text { Зна- } \\
\text { чення }\end{array}$ & $\begin{array}{l}\text { Кате- } \\
\text { горії }\end{array}$ \\
\hline Хлориди & 20 & 1 & 30 & 2 & 13,43 & 1 & 20,50 & 2 \\
\hline Сульфати & 50 & 1 & 75 & 2 & 64,12 & 2 & 79,00 & 3 \\
\hline Мінералізація & 500 & 1 & 750 & 2 & 488,00 & 1 & 585,00 & 2 \\
\hline $\begin{array}{c}\text { Розчинений } \\
\text { кисень }\end{array}$ & 7,6 & 2 & 7,1 & 3 & 10,58 & 1 & 12,19 & 1 \\
\hline $\begin{array}{c}\text { Завислі } \\
\text { речовини }\end{array}$ & 10 & 2 & 20 & 3 & 13,50 & 3 & 32,80 & 5 \\
\hline $\mathrm{pH}$ & $6,8-7,9$ & 2 & $6,6-8,0$ & 3 & 8,00 & 3 & 8,05 & 3 \\
\hline $\begin{array}{c}\text { Азот } \\
\text { амонійний }\end{array}$ & 0,3 & 3 & 0,4 & 3,5 & 0,44 & 4 & 0,86 & 5 \\
\hline $\begin{array}{c}\text { Азот } \\
\text { нітратний }\end{array}$ & 0,5 & 3 & 0,6 & 3,5 & 2,16 & 6 & 3,12 & 7 \\
\hline $\begin{array}{c}\text { Азот } \\
\text { нітритний }\end{array}$ & 0,01 & 3 & 0,015 & 3,5 & 0,03 & 5 & 0,06 & 6 \\
\hline $\begin{array}{c}\text { Фосфор } \\
\text { фосфатів }\end{array}$ & 0,03 & 2 & 0,05 & 3 & 1,58 & 5 & 2,69 & 6 \\
\hline $\begin{array}{c}\text { Біхроматна } \\
\text { окисність } \\
\text { (ХСК) }\end{array}$ & 25 & 3 & 30 & 4 & 24,1 & 3 & 30,00 & 4 \\
\hline$\overline{\mathrm{LCK}}_{5}$ & 3,1 & 3,5 & 5,1 & 4,5 & 5,03 & 5 & 9,31 & 6 \\
\hline Залізо & 0,5 & 4 & 1,0 & 5 & 330,50 & 4 & 718,00 & 5 \\
\hline Мідь & 0,003 & 4 & 0,01 & 4,5 & 2,75 & 3 & 4,70 & 4 \\
\hline Цинк & 0,02 & 3 & 0,05 & 4 & 71,10 & 5 & 98,6 & 5 \\
\hline $\begin{array}{c}\text { Хром } \\
\text { загальний }\end{array}$ & $<0,002$ & 1 & 0,003 & 2 & $<2,00$ & 1 & $<2,00$ & 1 \\
\hline Нікель & $<<0,001$ & 1 & 0,005 & 2 & 3,73 & 2 & 5,50 & 3 \\
\hline Марганець & 0,026 & 3 & 0,051 & 4 & 112,68 & 5 & 165,10 & 5 \\
\hline Фториди & 0,15 & 3 & 0,20 & 4 & 225,00 & 5 & 250,00 & 5 \\
\hline АПАР & $<0,01$ & 2 & 0,02 & 3 & 26,50 & 4 & 44,00 & 4 \\
\hline
\end{tabular}

ЕН

ЕН

${ }^{17}$ Мельник В.Й. Екологічні нормативи якості води річок у межах Рівненської області : монографія. Рівне : О. Зень, 2015. 290 с. 
Визначення різниці між нормативними і фактичними значеннями кожного показника якості води у категоріях, значення якого i характеризує втрату, є критерієм для встановлення реальної кількісної величини екологічної втрати якості води р. Іква та її якісної оцінки.

Установлено, що з 20 досліджуваних показників утрата якості води визначена для $60 \%$ показників i завдана переважно органічним забрудненням, фосфатами, тріадою амонійної групи (азотом амонійним, нітритним та нітратним) (табл. 4).

Таблиця 4

Екологічна втрата якості води р. Іква (станом на 2019 р.)

\begin{tabular}{|c|c|c|c|c|c|c|}
\hline \multirow{2}{*}{ Показник } & \multicolumn{2}{|c|}{$\begin{array}{c}\text { Різниця } \\
\text { в категоріях } \\
\end{array}$} & \multicolumn{2}{|c|}{$\begin{array}{l}\text { Ступінь } \\
\text { втрати }\end{array}$} & \multicolumn{2}{|c|}{ Характеристика втрати } \\
\hline & cep. & макс. & cep. & макс. & cep. & макс. \\
\hline Хлориди & 0 & 0 & 0 & 0 & відсутня & відсутня \\
\hline Сульфати & -1 & -1 & I & I & незначна & незначна \\
\hline Мінералізація & 0 & 0 & 0 & 0 & відсутня & відсутня \\
\hline $\begin{array}{c}\text { Розчинений } \\
\text { кисень }\end{array}$ & 0 & 0 & 0 & 0 & відсутня & відсутня \\
\hline $\begin{array}{c}\text { Завислі } \\
\text { речовини }\end{array}$ & -1 & -2 & I & II & незначна & значна \\
\hline $\mathrm{pH}$ & -1 & 0 & I & 0 & незначна & відсутня \\
\hline $\begin{array}{c}\text { Азот } \\
\text { амонійний }\end{array}$ & -1 & $-1,5$ & I & II & незначна & значна \\
\hline $\begin{array}{c}\text { Азот } \\
\text { нітратний }\end{array}$ & -3 & $-3,5$ & III & IV & загрозлива & катастроф. \\
\hline $\begin{array}{c}\text { Азот } \\
\text { нітритний }\end{array}$ & -2 & $-2,5$ & II & III & значна & загрозлива \\
\hline $\begin{array}{c}\text { Фосфор } \\
\text { фосфатів }\end{array}$ & -3 & -3 & III & III & загрозлива & загрозлива \\
\hline $\begin{array}{c}\text { Біхроматна } \\
\text { окисн. (ХCК) }\end{array}$ & 0 & 0 & 0 & 0 & відсутня & відсутня \\
\hline $\mathrm{БCK}_{5}$ & $-1,5$ & $-1,5$ & II & II & значна & значна \\
\hline Залізо & 0 & 0 & 0 & 0 & відсутня & відсутня \\
\hline Мідь & 0 & 0 & 0 & 0 & відсутня & відсутня \\
\hline Цинк & -2 & -1 & II & $\mathrm{I}$ & значна & незначна \\
\hline $\begin{array}{c}\text { Хром } \\
\text { загальний }\end{array}$ & 0 & 0 & 0 & 0 & відсутня & відсутня \\
\hline Нікель & -1 & -1 & I & II & незначна & незначна \\
\hline Марганець & -2 & -1 & II & $\mathrm{I}$ & значна & незначна \\
\hline Фториди & -2 & -1 & II & $\mathrm{I}$ & значна & незначна \\
\hline АПАР & -2 & -1 & II & $\mathrm{I}$ & значна & незначна \\
\hline
\end{tabular}


Нами запропоновано класифікацію втрати якості води, за якою проведено оцінку втрати якості води р. Іква у межах Рівненської області (табл. 5).

Таблиця 5

\section{Оцінка втрати якості води р. Іква у межах Рівненської області} (станом на 2019 р.)

\begin{tabular}{|c|c|c|c|c|c|}
\hline \multirow{2}{*}{$\begin{array}{l}\text { Різниця в } \\
\text { категоріях }\end{array}$} & \multirow{2}{*}{$\begin{array}{l}\text { Відхилення } \\
\text { від ЕН } \mathrm{EH}_{0} \%\end{array}$} & \multirow{2}{*}{$\begin{array}{c}\text { Ступінь } \\
\text { втрати } \\
\text { якості води }\end{array}$} & \multicolumn{2}{|c|}{ Кількість показників } & \multirow{2}{*}{$\begin{array}{c}\text { Характеристика } \\
\text { ступеня втрати }\end{array}$} \\
\hline & & & $\begin{array}{c}\text { Середні } \\
\text { значення }\end{array}$ & $\begin{array}{l}\text { Найгірші } \\
\text { значення }\end{array}$ & \\
\hline $0,5-1,4$ & до 20 & I & 5 & 6 & незначна \\
\hline $1,5-2,4$ & до 35 & II & 6 & 3 & значна \\
\hline $2,5-3,4$ & до 50 & III & 1 & 2 & загрозлива \\
\hline $3,5-7,0$ & $>50$ & IV & - & 1 & катастрофічна \\
\hline
\end{tabular}

3'ясовано, що «незначна» втрата якості води визначена для $25 \%$ середніх та 30\% найгірших значень показників. «Значна» втрата якості води встановлена для $30 \%$ середніх та $15 \%$ найгірших значень показників. Для 5\% середніх і $10 \%$ найгірших значень показників втрата $\epsilon$ «загрозливою» і для 5\% найгірших значень втрата якості води визначена як «катастрофічна».

\section{2. Оцінка антропогенного навантаження на басейн р. Іква}

Поняття антропогенного впливу на річки України розкрито в працях В.I. Вишневського, Й.В. Гриба, М.О. Клименка, А.В. Яцика, В.С. Холоденко та ін. ${ }^{18,19,20,21,22,23,24}$, проте відсутня кількісна й якісна

${ }^{18}$ Вишневський В.І. Антропогенний вплив на річки України : автореф. дис. ... д-ра геогр. наук : 11.00 .11 ; Львів. нац. ун-т ім. І. Франка. Львів, 2003. 35 с.

${ }_{19}$ Нормирование аллохтонных нагрузок на водную среду речных бассейнов в пределах урбанизированных территорий / В.В. Сондак та ін. Вісник НУВГП. 2014. Вип. 2. С. 116-126.

${ }_{20}$ Клименко М.О., Вознюк Н.М., Буднік 3.М. Характеристика басейну р. Іква. Вісник НУВГП. 2011. Вип. 2(54). С. 11-16.

21 Клименко М.О., Буднік 3.М. Дослідження зміни якості поверхневих вод в басейні річки Іква / А.В. Яцик та ін. Вісник НУВГП. 2013. Вип. 2. С. 87-95.

${ }^{22}$ Водні ресурси: використання, охорона, відтворення, управління. Київ : Генеза, 2007. 360 c.

${ }_{23}$ Холоденко В.С. Антропогенний вплив водокористувачів на стан річки Іква та його екологічний аспект. Географія та туризм. Київ, 2012. С. 304-311.

${ }^{24}$ Lavrov V.V., Blinkova O.I., Miroshnyk N.V. Anthropogenic changes in environmental conditions of phytocoenoses of medium-sized Ukrainian river valleys (based on the example of the River Tyasmyn - a tributary of the Dnieper). Visnyk of Dnipropetrovsk University. Т. 24. Вип. 2. С. 501-511. 
оцінка i класифікація басейнів за ступенем дії антропогенних навантажень.

Територія водозбору в басейні річки Іква зазнала сильних змін унаслідок гідротехнічних меліорацій і використовується в сільському господарстві. Із загальної площі меліорованих земель 45,377 тис га в сільськогосподарському виробництві використовується 89,5\%, із них під посівом сільськогосподарських культур 24,9\%. Догляд і утримання осушувальної мережі, значна частина якої знаходиться в занедбаному стані, потребує особливої уваги. Забруднення басейну проходить у межах сільських населених пунктів через відсутність централізованої каналізації та неконтрольованих скидів стічних вод із приватних будинків. Установлено, що безконтрольне освоєння заплави річки, дачне будівництво, ерозійні процеси тощо призводять також до погіршення якості води в досліджуваній річці.

Вода р. Іква переважно використовується для господарських та виробничих потреб. Слід зазначити, що забір води з річки 3 кожним роком зменшується, і тільки за останні три роки обсяги споживання води відносно стабільні ${ }^{25}$. Забір води 3 річки у динаміці описаний цифровою моделлю, яка має вид полінома 4-го ступеня з коефіцієнтом детермінації $\mathrm{R}^{2}=0,9982$ (рис. 4).

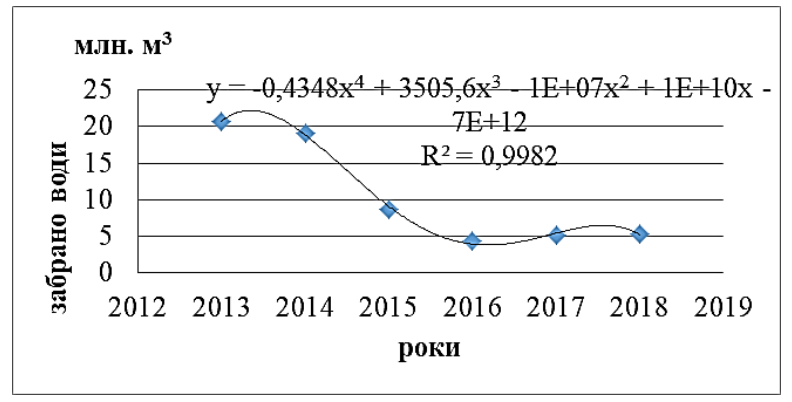

\section{Рис. 4. Водовикористання у басейні р. Іква}

Річка Іква - одна з багатьох середніх річок України, де зареєстрована велика кількість скидів стічних вод. Основними забруднювачами води річки є комунальні господарства та промислові підприємства м. Дубно та смт Млинів. Слід відзначити, що основне навантаження припадає на ділянку річки у межах Дубнівського району. Перенавантажені у

${ }^{25}$ Буднік 3.М. Комплексна оцінка якості води р. Іква в межах Дубенського району. Вісник НУВГП. 2015. Вип. 1(69). С. 23-31. 
півтора рази проєктної потужності із застарілою технологією очисні споруди біологічної очистки КП «Дубноводоканал» скидають у річку 6,2 тис м ${ }^{3}$ стічних вод на добу, русло не справлясться з навантаженням $i$ розбавлення води у річиі не відбувається до контрольного створу c. Івання. Значне розвантаження річки проходить у русловому водосховищі довжиною 7 км у Млинівському районі за рахунок акумуляції маломінералізованих вод весняних і літніх паводків. Рівень антропогенного навантаження становить 146,06 г $/ \mathrm{M}^{3} / \mathrm{KM}$, а стан водосховища оцінений III класом із характеристикою «задовільний» із потенційним переходом до IV класу ${ }^{26}$.

Забруднення річки проходить і в Млинівському районі за рахунок скидів недостатньо очищених, а впродовж 2016-2019 pp. неочищених стічних вод з очисних споруд ККП смт Млинів ${ }^{27,28}$. Скид стічної води у річку описаний цифровою моделлю, яка має вид полінома 3 -го ступеня 3 коефіцієнтом детермінації $\mathrm{R}^{2}=0,9449$ (рис. 5).

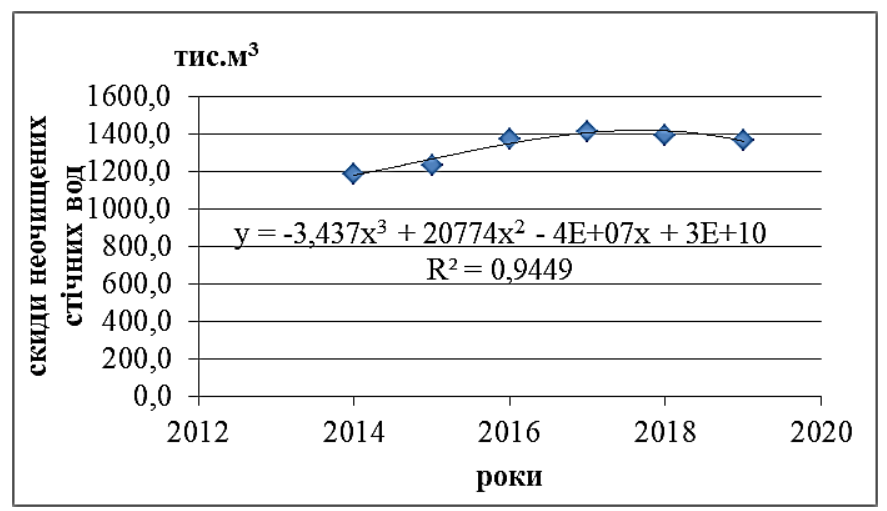

Рис. 5. Динаміка скидів забруднених стічних вод у р. Іква

Розрахунок антропогенного навантаження i класифікація екологічного стану басейну річки Іква проведені за «Методикою...» ${ }^{29}$,

${ }^{26}$ Нормирование аллохтонных нагрузок на водную среду речных бассейнов в пределах урбанизированных территорий / В.В. Сондак та ін. Вісник НУВГП. 2014. Вип. 2. С. 116-126.

27 Доповідь про стан навколишнього природного середовища в Рівненській області за 2014-2018 pp. Рівне, 2015-2019. 280 с., 312 с., 222 с., 236 с., 241 с.

${ }_{28}^{28}$ Статистична звітність, щорічна форма 2ТП «Водгосп» (2015-2019 рр.).

29 Методика розрахунку антропогенного навантаження i класифікації екологічного стану басейнів малих річок України / ред. А. В. Яцик, О. П. Канаш, В. А. Сташук та ін. Київ: УНДІВЕП, 2007. 71 с. 
в основу якої покладено блочний принцип, що дає змогу автономно вирішувати декілька різних завдань. Для оцінки антропогенного навантаження на басейн річки запропоновано чотири блоки (підсистеми), які характеризуються набором критеріїв і показників, за якими класифікували стан басейну річки відносно кожного показника, а за їх оцінками - всієї підсистеми.

\section{Підсистема «Радіоактивне забруднення території»}

За даними дозиметричної паспортизації районів, щільність забруднення грунтів у басейні $p$. Іква цезієм-137 становить 0,03-1,8 Ki $/ \mathrm{Kм}^{2}$, стронцієм-90 - до $0,05 \mathrm{Ki} / \mathrm{Kм}^{2}$. За установленими критеріями стан підсистеми «Радіоактивне забруднення території» класифікується як «задовільний». Міра підсистеми $\varphi\left(R_{i}\right)=\varphi\left(R_{l}\right)=0$.

\section{Підсистема «Використання земель»}

Оцінку використання земель водозбірної площі р. Іква проведено за даними Державної статистичної звітності головного управління Держгеокадастру у Рівненській області, форма «6-3ЕМ» ${ }^{30}$. За природно-сільськогосподарським районуванням території України басейн р. Іква розташований у Поліській західній провінції. Підсистема характеризується головними показниками $\mathrm{f}_{\mathrm{i}}$, за якими оцінювали величину антропогенного впливу (рис. 6).

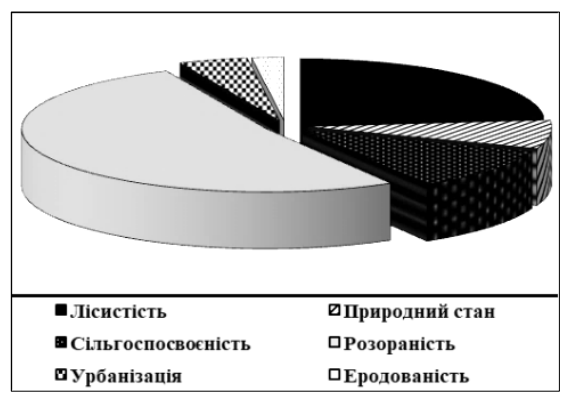

\section{Рис. 6. Показники підсистеми «Використання земель» р. Іква, \%}

Якісну оцінку рівня використання земель $\mathrm{U}\left(\mathrm{f}_{\mathrm{i}}\right)$ у басейні річки за кожним показником отримали шляхом обчислення величин показників. Значення ж спільного впливу всіх показників у підсистемі на іiї стан

${ }^{30}$ Статистична звітність 3 кількісного обліку земель форма 6-3ЕМ головного управління Держгеокадастру в Рівненській області (2018р.). 
з урахуванням вагових коефіцієнтів розрахували за методикою ${ }^{31}$. Установлено, що узагальнений стан підсистеми «Використання земель» «украй незадовільний», а значення показника класу підсистеми $=(-2,5)$ (табл. 6).

Таблиця 6

Підсистема «Використання земель»

\begin{tabular}{|c|c|c|c|c|}
\hline Показник & $\begin{array}{c}\text { Значення } \\
\text { показника }\end{array}$ & Стан системи & $\begin{array}{c}\text { Ваговий } \\
\text { коефіціснт }\end{array}$ & Міра \\
\hline Лісистість $\left(\mathrm{f}_{1}\right), \%$ & 22,0 & $\begin{array}{c}\mathrm{U}_{5}, \\
\text { «незадовільний» }\end{array}$ & 0,3 & -4 \\
\hline $\begin{array}{c}\text { Природний стан } \\
\left(\mathrm{f}_{2}\right), \%\end{array}$ & 6,8 & $\begin{array}{c}\mathrm{U}_{5}, \\
\text { «незадовільний» }\end{array}$ & 0,2 & -4 \\
\hline $\begin{array}{c}\text { Сільгоспосвоєність } \\
\left(\mathrm{f}_{3}\right), \%\end{array}$ & 66,7 & $\begin{array}{c}\mathrm{U}_{5}, \\
\text { «незадовільний» }\end{array}$ & 0,1 & -4 \\
\hline Розораність $\left(\mathrm{f}_{4}\right), \%$ & 48,8 & $\begin{array}{c}\mathrm{U}_{5}, \\
\text { «незадовільний» }\end{array}$ & 0,2 & -4 \\
\hline Урбанізація $\left(\mathrm{f}_{5}\right), \%$ & 4,3 & $\begin{array}{c}\mathrm{U}_{4}, \\
\text { «нижче норми» }\end{array}$ & 0,1 & -1 \\
\hline Еродованість $\left(\mathrm{f}_{6}\right)$ & $\begin{array}{c}\text { « } \\
\text { тис.га/рік }\end{array}$ & $\mathrm{U}_{1}$, «добрий» & 0,1 & 4 \\
\hline Узагальнений стан & $-2,5$ & \multicolumn{2}{|c|}{$\mathrm{L}_{5}$, «вкрай незадовільний» } \\
\hline
\end{tabular}

\section{Підсистема "Використання річкового стоку»}

За даними департаменту екології та природних ресурсів у Рівненській області проведено обчислення показників підсистеми (рис. 7).

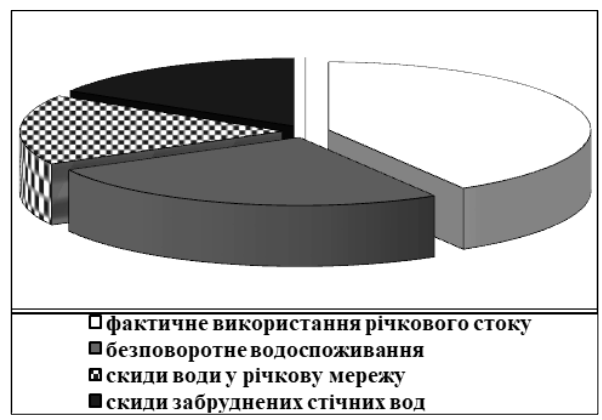

Рис. 7. Показники підсистеми «Використання річкового стоку» р. Іква, \%

31 Методика розрахунку антропогенного навантаження i класифікації екологічного стану басейнів малих річок України / ред. А.В. Яцик та ін. Київ : УНДІВЕП, 2007. $71 \mathrm{c}$. 
Якісну й кількісну оцінку рівня використання річкового стоку в басейні р. Іква по кожному значенню показників $\mathrm{g}_{\mathrm{i}}$ визначали за формулами на підставі отриманих даних, які становили: фактичний об'єм річкового стоку - 101,7 млн м³ ; об'єм забору води - 5,28 млн м ${ }^{3}$; об'єм скиду води - 2,08 млн м³ ; об'єм скиду забруднених стічних вод 2,02 млн м $^{3}$. Значення спільного впливу всіх показників підсистеми визначали за методикою (табл. 7).

Таблиця 7

Підсистема «Використання річкового стоку»

\begin{tabular}{|c|c|c|c|c|}
\hline Показник & $\begin{array}{c}\text { Значення } \\
\text { показника, } \\
\text { \% }\end{array}$ & $\begin{array}{c}\text { Стан } \\
\text { системи }\end{array}$ & $\begin{array}{c}\text { Ваговий } \\
\text { коефіціснт }\end{array}$ & Міра \\
\hline $\begin{array}{c}\text { Фактичне } \\
\text { використання } \\
\text { річкового стоку, } \mathrm{q}_{1}\end{array}$ & 5,09 & $\mathrm{U}_{1}$, «добрий» & 0,1 & 3 \\
\hline $\begin{array}{c}\text { Безповоротне } \\
\text { водоспоживання, } \mathrm{q}_{2}\end{array}$ & 3,15 & $\mathrm{U}_{1}$, «добрий» & 0,2 & 3 \\
\hline $\begin{array}{c}\text { Скид води у річкову } \\
\text { мережу, q }\end{array}$ & 2,08 & $\mathrm{U}_{1}$, «добрий» & 0,3 & 3 \\
\hline $\begin{array}{c}\text { Скид забруднених } \\
\text { стічнх вод, } \mathrm{q}_{4}\end{array}$ & 2,02 & $\begin{array}{c}\mathrm{U}_{3}, \\
\text { «поганий» }\end{array}$ & 0,4 & -1 \\
\hline Узагальнений стан & 1,4 & \multicolumn{2}{|c|}{$\mathrm{W}_{2}$ «задовільний» } \\
\hline
\end{tabular}

\section{Підсистема «Якість води»}

Підсистема характеризує антропогенний вплив скидів забруднених вод на якість води в річці. Якість води в р. Іква визначено за «Методикою...»" ${ }^{32}$ (табл. 8).

На підставі поточних значень мір окремих підсистем визначили індукційний коефіцієнт антропогенного навантаження (IКАН) басейну (табл. 9).

Для басейну р. Іква станом на 2019 р. значення показника індукційного коефіцієнта антропогенного навантаження становить 0,47, що відповідає «поганому» екологічному стану басейну.

Для дослідження міри змін якості води в кожному досліджуваному контрольному створі і загалом по річці в межах Рівненської області нами розраховано антропогенний складник змін якості води в р. Іква.

32 Методика екологічної оцінки якості поверхневих вод за відповідними категоріями / за заг. ред. В.Д. Романенко та ін. Київ : Символ-Т, 1998. 28 с. 
Таблиця 8

Підсистема «Якість води»

\begin{tabular}{|c|c|c|}
\hline Показник & Індекс & Оцінка показника \\
\hline Блок показників сольового складу, $\mathrm{I}_{1}$ & 2,0 & $\begin{array}{c}\text { II клас, } 2 \text { субкатегорія, вода } \\
\text { «чиста», стан «добрий» }\end{array}$ \\
\hline $\begin{array}{c}\text { Блок трофо-сапробіологічних } \\
\text { показників, } \mathrm{I}_{2}\end{array}$ & 4,9 & $\begin{array}{c}\text { III клас, } 5 \text { субкатегорія, вода } \\
\text { «забруднена», стан } \\
\text { «задовільний» } \\
\end{array}$ \\
\hline $\begin{array}{c}\text { Блок специфічних показників токсичної } \\
\text { дії, } \mathrm{I}_{3}\end{array}$ & 4,0 & $\begin{array}{c}\text { III клас, } 4 \text { субкатегорія, вода } \\
\text { «забруднена», стан } \\
\text { «задовільний» }\end{array}$ \\
\hline Інтегральний екологічний індекс, $\mathrm{I}_{\mathrm{e}}$ & 3,6 & $\begin{array}{c}\text { II-III клас, 3-4 субкатегорія, } \\
\text { вода перехідна від «чистої» до } \\
\text { «забрудненої», стан перехідний } \\
\text { від «доброго» до } \\
\text { «задовільного» }\end{array}$ \\
\hline $\begin{array}{c}\text { Узагальнений стан підсистеми «Якість } \\
\text { води» за ступенем чистоти за } \\
\text { найгіршими показниками }\end{array}$ & $\begin{array}{l}\text { Mipa } \\
0\end{array}$ & $\mathrm{Q}_{3}$ «слабко забруднені» \\
\hline
\end{tabular}

Таблиця 9

Загальний екологічний стан басейну р. Іква

\begin{tabular}{|c|c|c|c|c|c|c|c|c|c|}
\hline \multicolumn{2}{|c|}{$\begin{array}{c}\text { Підсистема } \\
\text { «Радіоактивне } \\
\text { забруднення» }\end{array}$} & \multicolumn{2}{|c|}{$\begin{array}{c}\text { Підсистема } \\
\text { «Вкористання } \\
\text { земель» }\end{array}$} & $\begin{array}{c}\text { Підсистема } \\
\text { «вкориста } \\
\text { ння } \\
\text { річкового } \\
\text { стоку» }\end{array}$ & \multicolumn{2}{|c|}{$\begin{array}{c}\text { Підсистема } \\
\text { «якість } \\
\text { води» }\end{array}$} & \multicolumn{2}{|c|}{$\begin{array}{c}\text { Загальний } \\
\text { екологічний } \\
\text { стан }\end{array}$} \\
\hline Стан & Miра & Стан & Мipa & Стан & $\begin{array}{c}\text { Мi } \\
\text { ра }\end{array}$ & $\begin{array}{c}\text { Катего } \\
\text { рія }\end{array}$ & $\begin{array}{c}\text { Mi } \\
\text { ра }\end{array}$ & Стан & $\begin{array}{c}\text { IКА } \\
\text { Н }\end{array}$ \\
\hline $\begin{array}{c}\text { задові- } \\
\text { льний }\end{array}$ & 0 & $\begin{array}{c}\text { вкрай } \\
\text { неза- } \\
\text { довільн } \\
\text { ий }\end{array}$ & $-2,5$ & $\begin{array}{c}\text { Задові } \\
\text { льна }\end{array}$ & 1,4 & $2-3$ & 0 & $\begin{array}{c}\text { поган } \\
\text { ий }\end{array}$ & 0,47 \\
\hline
\end{tabular}

Відсоток утрати якості води у контрольних створах нижче джерела впливу порівняно з контрольними створами вище впливу розрахований для основних забруднюючих речовин річки (табл. 10).

Установлено, що найвищі показники антропогенного складника загалом по р. Іква в межах області визначені для завислих речовин, фосфору фосфатів, марганцю та хлоридів. Слід зауважити, що на ділянці річки в контрольному створі нижче скиду стічних вод очисних споруд КП «Дубноводоканал» утрата якості води за БСК 5 , азотом амонійним та фосфатами значно вища і річка не розвантажується аж до гирла, тобто на ділянці довжиною 41 км, ураховуючи наявність зарусленого водосховища. Показники антропогенного складника в гирлі річки є найвищими, що вказує на загрозливий екологічний стан річки. На нашу думку, це пояснюється високим відсотком 
еродованості, низьким відсотком лісистості та природного стану, високим показником сільгоспосвоєності басейна та постійними скидами неочищених стічних вод.

Таблиця 10

Антропогенний складник змін якості води р. Іква у межах Рівненської області, \%

\begin{tabular}{|c|c|c|c|c|c|c|c|c|c|}
\hline Створ & $\mathrm{SO}_{4}{ }^{2-}$ & $\mathrm{Cl}^{-}$ & $\begin{array}{l}\text { Завис. } \\
\text { речов. }\end{array}$ & БСК $_{5}$ & $\begin{array}{c}\mathrm{N} \\
\left(\mathrm{NH}_{4}^{+}\right)\end{array}$ & $\begin{array}{c}\mathrm{N} \\
\left(\mathrm{NO}_{3}^{-}\right)\end{array}$ & $\begin{array}{c}\mathrm{N} \\
\left(\mathrm{NO}_{2}^{-}\right)\end{array}$ & $\begin{array}{c}\mathrm{P} \\
\left(\mathrm{PO}_{4}{ }^{3}\right)^{3}\end{array}$ & $\mathrm{Mn}^{2+}$ \\
\hline $\begin{array}{c}\text { сc. } \\
\text { Сапанівчик } \\
\text { - Дитиничі }\end{array}$ & 3,4 & & & & 32,6 & & & 40,5 & \\
\hline $\begin{array}{c}\text { м. Дубно } \\
\text { вище і } \\
\text { нижче } \\
\text { скиду о/с } \\
\end{array}$ & 18,2 & 7,3 & & 44,5 & 61,5 & 11,2 & 50,0 & 37,1 & - \\
\hline $\begin{array}{c}\text { нижче } \\
\text { скиду о/с с. } \\
\text { Івання }\end{array}$ & & & 12,7 & 16,0 & & & & & - \\
\hline $\begin{array}{l}\text { сс. Івання - } \\
\text { Торговиця }\end{array}$ & 10,0 & 30,7 & 69,5 & & & & 50,0 & 46,9 & 45,9 \\
\hline \multicolumn{10}{|c|}{ Загалом по річці } \\
\hline $\begin{array}{c}\text { cc. } \\
\text { Сапанівчик } \\
- \\
\text { Торговиця }\end{array}$ & 16,8 & 26,8 & 65,9 & 9,0 & & & & 39,4 & 33,4 \\
\hline
\end{tabular}

Поліпшення екологічного стану басейну р. Іква можливе лише у разі застосування низки природоохоронних та водоохоронних заходів, спрямованих на боротьбу з проблемами і джерелами забруднення, які будуть основною ланкою в системі заходів, спрямованих на поліпшення управління водокористуванням річки.

\section{ВИСНОВКИ}

Основними проблемами екологічного стану басейну річки Іква в сучасний період $\epsilon$ :

- безконтрольне освоєння заплави річки, гідротехнічні меліорації в басейні, використання води для господарських та виробничих потреб, ерозійні процеси, дачне будівництво, неконтрольовані скиди стічних вод із приватних будинків;

- погіршення якості води річки визначено за значеннями як усіх блокових, так і інтегрального екологічного індексів. Апріорі в оцінці якості води надано показникам трофо-сапробіологічного блоку, за ступенем чистоти вода охарактеризована як «забруднена» із 
«задовільним» станом, III класу, евтрофна, $\beta$ ”-мезосапробна за середніми і найгіршими значеннями показників;

- різниця між якістю води в сучасний період і встановленими екологічними нормативами становить від $(-1,0)$ до $(-3,5)$ категорії, що відповідає від 20\% до 50 \% відхилень від екологічних нормативів;

- загальна втрата якості води характерна для 60\% показників і охарактеризована I-IV ступенем утрати з оцінкою від «незначної» до «катастрофічної»;

- якісний стан системи «Басейн річки Іква» за показниками антропогенного навантаження визначений як «поганий» за IКАН $(-0,47)$;

- високі показники антропогенного складника загалом по р. Іква в межах області характерні переважно для завислих речовин, фосфору фосфатів, марганцю та хлоридів і становлять 65,9\%; 39,4\%; 33,4\% та 26,8 \% відповідно, а найвищі показники зафіксовані в гирлі річки, що вказує на загрозливий їі екологічний стан.

\section{АНОТАЦІЯ}

Робота розкриває основні проблеми сучасного стану басейну р. Іква в межах Рівненської області. Проаналізовано теоретичні та методичні підходи до системного дослідження стану басейну і змін під впливом антропогенного навантаження, розглянуто сучасний стан вивчення проблем досліджуваного басейну. Здійснено комплексну оцінку якості води річки, розкрито поняття «втрата якості води», «антропогенний складник», установлено міри змін якості води. 3'ясовано, що вода річки за найгіршими значеннями показників віднесена до III класу забруднення і від 20\% до 50\% не відповідає значенням екологічних нормативів. Установлено, що втрата якості води характерна для $60 \%$ показників і охарактеризована I-IV ступенем утрати 3 оцінкою від «незначної» до «катастрофічної». Дослідження антропогенного впливу на басейн річки свідчать, що основний вплив чинять показники підсистем «Використання земель» та «Використання річкового стоку», стан яких класифікований як «украй незадовільний» і «задовільний» відповідно, а якісний стан басейну р. Іква - як «поганий» за ІКАН $(-0,47)$. Показники антропогенного складника якості води визначено для завислих речовин, фосфору фосфатів, марганцю та хлоридів і становлять від $26,8 \%$ до $65,9 \%$, найвищі показники зафіксовані в гирлі річки із загрозливим їі екологічним станом. 


\section{ЛIТЕРАТУРА}

1. Бедункова О.О., Буднік 3.М. Оцінка екологічної шкоди та екологічного ризику гідрохімічних показників річки Іква. Вісник НУВГП. 2012. Вип. 4(60). С. 77-82.

2. Боярин М. Управління водними ресурсами басейну річки Іква в межах Рівненсьої області. Науковий вісник Східноєвропейського національного університету ім. Л. Українки. 2013. С. 38-42.

3. Буднік 3.М. Комплексна оцінка якості води р. Іква в межах Дубенського району. Вісник НУВГП. 2015. Вип. 1(69). С. 23-31.

4. Екологічна оцінка стану поверхневих вод України з урахуванням регіональних гідрохімічних особливостей / О.Г. Васенко та ін. Проблеми охорони навколишнього природного середовища та екологічної безпеки. 2010. Вип. XXXII. С. 36-54.

5. Вишневський B.I. Антропогенний вплив на річки України : автореф. дис. ... д-ра геогр. наук : 11.00 .11 ; Львів. нац. ун-т ім. I. Франка. Львів, 2003. 35 с.

6. Ганущак М.М. Роль водного чинника в розвитку і функціонуванні природно-антропогенних комплексів басейну p. Стир : дис. ... канд. геогр. наук : 11.00 .11 ; Східноєвроп. нац. ун-т ім. Л. Українки. Луцьк, 2016. 242 с.

7. Доповідь про стан навколишнього природного середовища в Рівненській області за 2014-2018 рр. Рівне, 2015-2019. 280 с., 312 с., 222 c., 236 c., 241 c.

8. Клименко М.О., Вознюк Н.М., Буднік 3.М. Характеристика басейну р. Іква. Вісник НУВГП. 2011. Вип. 2(54). С. 11-16.

9. Клименко М.О., Буднік 3.М. Дослідження зміни якості поверхневих вод в басейні річки Іква. Вісник НУВГП. 2013. Вип. 2. C. 87-95.

10. Коротун І.М., Коротун Л.К. Географія Рівненської області. Рівне, 1996. 273 с.

11. Гідроекологічна характеристика басейну річки Іква та оцінка його стану / О.М. Лєтицька та ін. Наукові записки Тернопільського національного педагогічного університету ім. В. Гнатюка. 2013. Вип. 3(56). С. 61-66.

12. Мельник В.Й. Екологічні нормативи якості води річок у межах Рівненської області : монографія. Рівне : О. Зень, 2015. 290 с.

13. Методика екологічної оцінки якості поверхневих вод за відповідними категоріями / за заг. ред. В.Д. Романенко та ін. Київ : Символ-Т, 1998. 28 с.

14. Методика розрахунку антропогенного навантаження і класифікації екологічного стану басейнів малих річок України / ред. А.В. Яцик та ін. Київ : УНДІВЕП, 2007. 71 с. 
15. Нормирование аллохтонных нагрузок на водную среду речных бассейнов в пределах урбанизированных территорий / В.В. Сондак та ін. Вісник НУВГП. 2014. Вип. 2. С. 116-126.

16. Статистична звітність, щорічна форма 2ТП «Водгосп» (2015-2019 pp.).

17. Статистична звітність із кількісного обліку земель, форма 6-3ЕМ головного управління Держгеокадастру в Рівненській області (2018 p.).

18. Холоденко В.С. Антропогенний вплив водокористувачів на стан річки Іква та його екологічний аспект. Географія та туризм. 2012. С. 304-311.

19. Водні ресурси: використання, охорона, відтворення, управління / А.В. Яцик та ін. Київ : Генеза, 2007. 360 с.

20. Brannen L., Bielak A. (ed.) Threats to water availability in Canada. National Water Research Institute, Environment Canada, 2004.

21. Gilvear D.J., Spray C.J., Casas-Mulet R. River rehabilitation for the delivery of multiple ecosystem services at the river network scale. J. Environ. Manage. 2013. № 126. P. 30-43. DOI: 10.1016/j.jenvman.2013.03.026.

22. Lavrov V.V., Blinkova O.I., Miroshnyk N.V. Anthropogenic changes in environmental conditions of phytocoenoses of medium-sized Ukrainian river valleys (based on the example of the River Tyasmyn - a tributary of the Dnieper). Visnyk of Dnipropetrovsk University. Т. 24. Вип. 2. С. 501-511.

Information about the authors: Melnyk V. Y.,

Candidate of Geographical Sciences, Professor at the Department of Natural Sciences with Teaching Methods

Rivne State Humanitarian University 12, Stepana Bandery str., Rivne, 33028, Ukraine

Tolochyk I. L.,

Candidate of Biological Sciences, Associate Professor at the Department of Biology, Human Health and Physical Therapy

Rivne State Humanitarian University 12, Stepana Bandery str., Rivne, 33028, Ukraine 